\title{
The nutrition of the hill cow
}

\author{
By D. M. Allen, Meat and Livestock Commission, \\ Bletchley, Bucks
}

\section{Introduction}

The hill environment is characterized by high rainfall and wind speeds and a short growing season of sparse pastures. For the purposes of this paper, land classified for statutory purposes as hill land but which is strictly improved upland or upland capable of improvement is excluded from the discussion.

The objective here is to examine the effects of nutrition on performance with special reference to energy and protein requirements. Major minerals, such as phosphate and several trace elements which are commonly deficient in leached acid soils and which can have important effects on performance, are discussed at this symposium by Hemingway (r97r).

\section{Targets of performance}

It is important to discuss the nutrition of hill cows in relation to targets of performance which are possible in that environment. Tentative targets are suggested in Table $\mathrm{I}$. The weaning percentage has a profound influence on profitability and also of major significance is the weaning weight of calves which has a direct effect on financial returns.

Table I. Targets of performance and mean recorded performances in hill and upland suckler herds (winter-spring calving)

\begin{tabular}{|c|c|c|c|c|c|c|}
\hline & $\begin{array}{l}\text { Calving } \\
\text { interval } \\
\text { (d) }\end{array}$ & $\begin{array}{c}\text { Barren } \\
\text { cows } \\
(\%)\end{array}$ & $\begin{array}{l}\text { Calf } \\
\text { mortality } \\
\text { and } \\
\text { stillbirths } \\
(\%)\end{array}$ & $\begin{array}{l}\text { Calves } \\
\text { weaned } \\
\text { / roo cows } \\
\text { bulled } \\
\text { (no.) }\end{array}$ & $\begin{array}{c}\text { Calf wt } \\
\text { gain to } \\
\text { weaning } \\
\text { (kg/d) }\end{array}$ & $\begin{array}{c}200-\mathrm{d} \\
\text { weaning } \\
\text { wt } \\
(\mathrm{kg})\end{array}$ \\
\hline $\begin{array}{l}\text { Performance } \\
\text { Target } \\
\text { Mean recorded: }\end{array}$ & 365 & 7 & $\sqrt{107}$ & 88 & 0.78 & 184 \\
\hline $\begin{array}{l}\text { Upland herds } \\
\text { Hill herds }\end{array}$ & - & $\begin{array}{l}4 \cdot 6 \\
9 \cdot 3\end{array}$ & $\begin{array}{l}3.4 \\
5.6\end{array}$ & $\begin{array}{l}9 \times \cdot 7 \\
84 \cdot 3\end{array}$ & $\begin{array}{l}0.78 \\
0.68\end{array}$ & $\begin{array}{l}187 \\
168\end{array}$ \\
\hline
\end{tabular}

Mean performance in hill herds recorded by the Meat and Livestock Commission is also shown in Table I which includes results from upland herds for comparison. The weaning percentage was below target largely because of the rather high percentage of barren cows; calf gains were also below target. A feature of the results is the wide variation between farms. Weaning percentages ranged from 74 to 96 and calf gains from 0.5 to $1.0 \mathrm{~kg}$ per $\mathrm{d}$. These results suggest strongly that nutrition is the main factor limiting performance.

This suggestion is further supported by an examination of the performance of $30(3) 2$ 
different breeds and crosses in upland and hill herds recorded by the Meat and Livestock Commission (Table 2). In upland herds there was a substantial influence of breed of sire on calf performance but, although this influence was still apparent in hill herds, it was substantially reduced. The effect of type of dam, illustrated by a comparison of the beef breed $\times$ Friesian cow with specialized beef cows, e.g. the Blue-Grey, was much smaller than the sire influence. However, although the increased milk potential of the cow carrying dairy blood resulted in heavier calves on upland farms, the difference on hill farms was greatly reduced. It is clear that in such a difficult environment cows of the native hill breeds, such as the Galloway and Welsh Black, have few competitors.

\section{Table 2. Comparative performances of different breeds and crosses in recorded upland and hill herds}

\begin{tabular}{|c|c|c|c|c|}
\hline \multicolumn{5}{|c|}{ Calf $200-\mathrm{d}$ weights $(\mathrm{kg})$} \\
\hline & \multicolumn{2}{|c|}{ Upland herds } & \multicolumn{2}{|c|}{ Hill herds } \\
\hline Type of dam & $\begin{array}{c}\text { Beef breed } x \\
\text { Friesian }\end{array}$ & $\begin{array}{l}\text { Beef } \\
\text { cow }\end{array}$ & $\underset{\text { Friesian }}{\text { Beef breed }} \times$ & $\begin{array}{l}\text { Beef } \\
\text { cow }\end{array}$ \\
\hline \multicolumn{5}{|l|}{ Breed of sire } \\
\hline Aberdeen Angus & 189 & 177 & 160 & 156 \\
\hline Beef Shorthorn & 186 & 172 & 155 & I5I \\
\hline Charolais & $22 I$ & 206 & 178 & I76 \\
\hline Galloway & 181 & 172 & 156 & I55 \\
\hline Hereford & 202 & 197 & 172 & 167 \\
\hline Red breeds (Devon, Lincoln Red, Sussex) & 220 & 207 & 174 & 170 \\
\hline Welsh Black & 197 & 185 & 170 & 168 \\
\hline
\end{tabular}

\section{Nutrition and performance}

Theoretical nutritional requirements can be assessed in relation to cow size and productive state, with adjustments for climatic exposure and the activity of foraging for feed. In fact, British data are sparse because, not only has research on beef cow nutrition been generally ignored until recently, but virtually no one has attempted serious work with the hill cow. Data collected in the USA are of limited value because they refer to an environment which imposes climatic stresses different from those existing on British hill farms. However, some New Zealand research may have application. Necessarily, therefore, any discussions of hill cow nutrition must be speculative.

There are two approaches to supplying feed in environments which limit animal performance. One is to adjust the feed supply to the productive requirements of stock. The other is to adjust stock to the available feed so that they pass through critical parts of the production cycle at the time of peak feed supplies but are allowed to lose weight when their requirements are not critical and feed supplies are short. In extensive farming the second approach tends to be adopted though some supplementary feeding is carried out. The main risk is that failure to meet critical requirements will probably have carry-over effects into the following production cycle and severe effects on lifetime productivity. 
In these terms the definition of critical periods becomes as important as the estimation of feed requirements. Critical periods probably include the final stages of pregnancy, the first 2 months of lactation and the mating period. Crude estimates of feed requirements, expressed as dry matter, at various stages of the production cycle are given in Table 3 . On forage-based diets, protein is unlikely to be limiting with a digestible crude protein requirement for maintenance of around $300 \mathrm{~g}$ per $\mathrm{d}$. However, during late pregnancy requirements rise to around $45^{\circ} \mathrm{g}$ per $\mathrm{d}$ and during early lactation to around $75^{\circ} \mathrm{g}$ per $\mathrm{d}$. During these periods protein supplementation may be necessary if forage is of low quality.

Table 3. Estimated dry-matter requirements $(\mathrm{kg} / \mathrm{d})$ of hill cows for feedstuffs supplying different amounts of metabolizable energy

\begin{tabular}{|c|c|c|c|c|}
\hline $\begin{array}{l}\text { Dietary concentration of metabolizable } \\
\text { energy (Mcal } / \mathrm{kg} \text { dry matter) }\end{array}$ & r.8 & $2 \cdot 2$ & $2 \cdot 6$ & 30 \\
\hline $\begin{array}{l}\text { Functional requirement } \\
\text { Maintenance (cow weighing } 425 \mathrm{~kg} \text { ) } \\
\text { Last month of pregnancy (calf birth }\end{array}$ & $6 \cdot I$ & 47 & 3.8 & 3.0 \\
\hline $\begin{array}{l}\text { weight } 30 \mathrm{~kg}) \\
\text { Peak lactation (Io kg milk } / \mathrm{d})\end{array}$ & $\begin{array}{l}10 \cdot 5^{*} \\
15 \cdot 4^{*}\end{array}$ & $\begin{array}{c}7 \cdot 9 \\
10 \cdot 8 *\end{array}$ & $\begin{array}{l}6 \cdot 0 \\
8 \cdot 3\end{array}$ & $\begin{array}{l}4^{\cdot 8} \\
7 \cdot 0\end{array}$ \\
\hline
\end{tabular}

*These intakes are probably above physical capacity.

Perhaps the most important time in relation to lifetime productivity is the mating period. This subject has recently been reviewed by Lamond (1970) who concludes that the relationship between nutrition and fertility is such that the fertility of lactating adult beef cows is a good index of nutritional status. It is difficult to decide whether body condition at mating or rate of change of condition at mating has the greatest influence on conception rates. Wiltbank (I970) presents conflicting evidence but Lamond proposes a hypothetical model suggesting thresholds of live weight below which cows in low body condition have low fertility regardless of current energy intake. By contrast, cows in high condition may have high fertility even though they are losing weight at mating. Because cows are inevitably in negative energy balance during early lactation, both body condition at calving and the rate at which depleted body reserves are restored during the pre-mating period are likely to be important.

Further, under conditions of nutritional stress inherently high milk yields may be a disadvantage because of the depletion of body reserves and subsequent low fertility. Lower-yielding cows may be better suited to the environment because, although they produce smaller calves at weaning, they may show better fertility and their calves regain most of their weight loss during the postweaning period. This supposition raises an important question for breeders of hill cattle in the emphasis they should place on selection for high milk yields.

A series of interesting experiments (Hight, $\mathrm{I} 968 a, b$ ) has sought to establish relationships between the effects of pre- and post-calving nutrition on performance. Low levels of feeding in the 3 months pre-partum reduced calf birth weight and weaning weight and increased calf mortality. Low levels of feeding post partum 
reduced weaning weight and, where the pre-partum level of feeding was also low, reduced fertility in the following season. It was concluded that pre- and postpartum feeding had equal effects on weaning weight. That short periods of high level feeding before calving produced satisfactory calves makes it possible to reduce maintenance requirements for the remainder of the dry period. Hight's work also demonstrated the ability of cows to rapidly regain live weight lost during periods of poor feeding when given high levels of feed.

Work of this type suggests patterns of feeding for optimum performance on hill farms. During the dry period from weaning up to $4^{-6}$ weeks before calving, cows can be allowed to lose some weight without detriment to subsequent performance provided this weight can be regained before the next mating. During the last 6 weeks before calving the level of feeding should be progressively increased to the equivalent of around maintenance plus $5 \mathrm{~kg}$ of milk and after calving to maintenance plus ro kg of milk. It should be maintained at this level until mating when the level can be gradually reduced to maintenance at weaning. Weaning calves somewhat earlier than is common practice would allow some economies in cow feed costs provided that high quality feed is available for the weaned calves. However, on most hill farms this procedure is of little relevance.

\section{Practical implimentation}

For spring calving cows the suggested pattern of feeding coincides fairly closely with seasonal feed supplies but as cows calve earlier in the year the feeding pattern becomes increasingly more difficult and expensive to achieve. Knowledge of the feeding levels in practice is only rudimentary. Also, for example, there is not even simple information on seasonal weight changes in hill cows. Notwithstanding the physical difficulties of working with hill cows this information requires collection without further delay.

\section{Cow size and efficiency}

It is generally accepted that breeds of small body size are best suited to the hill environment presumably because they are more efficient. In fact, an examination of weight-for-age information suggests differences in weight between hill breeds. For example Welsh Black bulls have a mean $500-\mathrm{d}$ weight $7^{6} \mathrm{~kg}$ greater than Galloway bulls and heifers $104 \mathrm{~kg}$ greater. These differences are almost certainly reflected in mature weight. However, such differences do not necessarily imply differences in efficiency.

How should efficiency be measured? An obvious measure, relevant to hill suckler herds, would be the total feed consumption of the cow and calf for each unit of calf weaning weight. Another measure, perhaps of greater relevance to the whole cattle industry, would be the total feed for each unit of slaughter weight. Although comparison of the two methods of measurement is unlikely to alter the ranking of breeds, it may reduce the differences between them.

The safest assumption, in the absence of clear evidence, is that there is no direct 
relationship between cow size and efficiency. This is illustrated by work in Texas (R. C. Thomas, personal communication) where the $320 \mathrm{~kg}$ Angus $\times$ Jersey cow mated with the Charolais required $12 \cdot 8 \%$ less feed for each $\mathrm{kg}$ of calf weaning weight than the $480 \mathrm{~kg}$ pure-bred Hereford and $9.5 \%$ less than the $550 \mathrm{~kg}$ pure-bred Charolais. For each $\mathrm{kg}$ of yearling weight the cross-bred Angus cow required $7 \%$ less feed than the Hereford and $5.6 \%$ less feed than the Charolais. More information of this type will be derived from experiments in North America but it seems unlikely that such detailed work will be repeated in Britain because of the large-scale facilities required. Because of variations of the ability of cows to forage and of suitability of herd social structures to the environment, results collected under carefully controlled experimental conditions may fail to give a complete answer.

With cows of a given body size efficiency can be radically improved if the growth potential of calves can be improved. The obvious approach is to cross hardy hill cows with breeds of higher growth potential but in practice the scope for crossbreeding may be limited by the need to breed a large proportion of the herd pure to ensure the replenishment of hill stocks.

\title{
REFERENCES
}

Hemingway, R. G. (1971). Proc. Nutr. Soc. 30, 22I.

Hight, G. K. (1968a). N.Z. fl agric. Res. I1, 71 .

Hight, G. K. (1968b). N.Z. $\mathscr{~ l l ~ a g r i c . ~ R e s . ~ I I , ~} 477$.

Lamond, D. R. (1970). Anim. Breed. Abstr. 38, 359.

Wiltbank, J. N. (1970), J. Anim. Sci., 31, 755.

\section{Physiological factors affecting the energy cost of cold exposures}

\author{
By J. SLeE, Agricultural Research Council, \\ Animal Breeding Research Organisation, Edinburgh EH9 $39 Q$
}

The immediate physiological consequences of cold exposure are well known. Sheep and cattle, the farm animals most commonly exposed to cold, display a variety of responses typical of homoeotherms. Apart from behavioural and postural adjustments, these include, first, piloerection, vasoconstriction and lowered respiratory rate; and secondly, shivering coupled with increases in heart rate, respiratory tidal volume and metabolic rate. The earlier responses reduce heat loss to the environment and are, therefore, energy-sparing. The other responses involve an increased energy demand. The ambient temperature below which heat production first increases is termed the lower critical temperature. The critical temperature is affected by the animal's physical insulation, which in turn is influenced by the morphology of the skin and the coat. Armstrong, Blaxter, Clapperton, Graham \& Wainman (1960) for sheep, and Blaxter (1964a) for sheep and cattle have discussed the relationships between coat length, insulation and the critical temperature, and assessed heat exchanges between the animal and the environment. Blaxter ( $1964 b)$ and Joyce \& Blaxter (1964) have shown how these relationships can be altered by the level of 